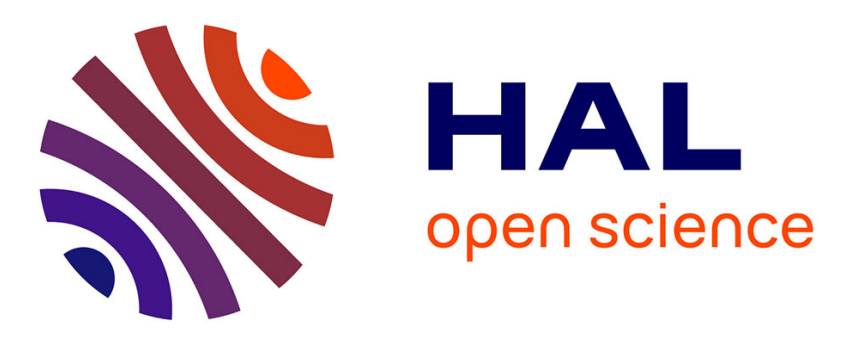

\title{
Assessment of Pneumocystis species carriage in captive primates
}

\author{
C. Demanche, Thierry Petit, Pierre Moisson, Florence Ollivet, Jacques \\ Rigoulet, René Chermette, Eduardo Dei-Cas, Ann E. Wakefield, Jacques \\ Guillot
}

\section{To cite this version:}

C. Demanche, Thierry Petit, Pierre Moisson, Florence Ollivet, Jacques Rigoulet, et al.. Assessment of Pneumocystis species carriage in captive primates. Veterinary Record, 2003, 152 (26), pp.811-813.

10.1136/vr.152.26.811 . hal-02680914

\section{HAL Id: hal-02680914 \\ https://hal.inrae.fr/hal-02680914}

Submitted on 31 May 2020

HAL is a multi-disciplinary open access archive for the deposit and dissemination of scientific research documents, whether they are published or not. The documents may come from teaching and research institutions in France or abroad, or from public or private research centers.
L'archive ouverte pluridisciplinaire HAL, est destinée au dépôt et à la diffusion de documents scientifiques de niveau recherche, publiés ou non, émanant des établissements d'enseignement et de recherche français ou étrangers, des laboratoires publics ou privés. 
standing. This surgical technique may also allow dyspnoea to be relieved while extended antibiotic or alternative therapies are administered.

\section{References}

ADAMS, O. R., BROWN, W. W., CHOW, T. L., COLLIER, J. R., DAVIS, R. W. GRINER, L. A., JENSEN, R., PIERSON, R. E. \& WAYT, L. K. (1959) Comparison of infectious bovine rhinotracheitis, shipping fever, and calf diphtheria of cattle. Journal of the American Veterinary Medical Association 134, 85-89

BRITTON, J. W. (1945) Further observations on chronic ovine laryngitis Cornell Veterinarian 35, 210-213

GASTHUYS, F., VERSCHOOTEN, F., PARMENTIER, D., DE MOOR, A. \& STEENHAUT, M. (1992) Laryngotomy as a treatment for chronic laryngeal obstruction in cattle: a review of 130 cases. Veterinary Record 130, 220-223

HAYNES, P. F. (1984) Surgery of the equine respiratory tract. In The Practice of Large Animal Surgery. Ed P. B. Jennings. London, W. B. Saunders. pp 388487

HAYNES, P. F., SNIDER, T. G., MCCLURE, J. R. \& MCCLURE, J. J. (1980) Chronic chondritis of the equine arytenoid cartilage. Journal of the American Veterinary Medical Association 177, 1135-1142

LANE, J. G., BROWN, P. J., LANCASTER, M. L. \& TODD, J. N. (1987) Laryngeal chondritis in Texel sheep. Veterinary Record 121, 81-84

LAWRENCE, J. A. (1967) Laryngeal abscesses in calves. Veterinary Record 81, 540-541

MCCLURE, S. R., TAYLOR, T. S., HONNAS, C. M., SCHUMACHER, J., CHAFFIN, M. K. \& HOFFMANN, A. G. (1995) Permanent tracheostomy in standing horses: technique and results. Veterinary Surgery 24, 231-234

MILNE, M. H., BARRETT, D. C., SULLIVAN, M. \& FITZPATRICK, J. L. (2000) Successful medical treatment of laryngeal chondritis in cattle. Veterinary Record 147, 305-306

Veterinary Record (2003) 152, 811-813

\section{Demanche,}

R. Chermette, DVM,

J. Guillot, DVM, PhD,

Equipe de Mycologie,

UMR 956, INRA-AFSSA-

ENVA-Paris XII Biologie

Moléculaire et

Immunologie Parasitaires

et Fongiques, Ecole

Nationale Vétérinaire

d'Alfort, 94704 Maisons-

Alfort, France

T. Petit, DVM,

Parc Zoologique de la

Palmyre, Les Mathes,

France

P. Moisson, DVM,

Parc Zoologique de

Mulhouse, France

F. Ollivet, DVM,

Parc Zoologique de

Vincennes, France

J. Rigoulet, DVM, Jardin

des Plantes de Paris,

France

E. Dei-Cas, $\mathrm{MD}, \mathrm{PhD}$,

Ecologie du Parasitisme,

Institut Pasteur de Lille,

France

A. E. Wakefield, $\mathrm{PhD}$,

Molecular Infectious

Diseases Group, Institute

of Molecular Medicine,

University of Oxford,

Oxford

Correspondence to

Professor Guillot

RADOSTITS, O. M., BLOOD, D. C. \& GAY, C. C. (1994) Diseases of the respiratory system. In Veterinary Medicine. London, Baillière Tindall. pp 391-434 SELMAN, I. E., WISEMAN, A., PIRIE, H. M. \& BREEZE, R. G. (1974) Fog fever in cattle: clinical and epidemiological factors. Veterinary Record 95, 139-146 SHAPPELL, K. K., STICK, J. A., DERKSEN, F. J. \& SCOTT, E. A. (1988) Permanent tracheostomy in equidae: 47 cases (1981-1986). Journal of the American Veterinary Medical Association 192, 939-942

SMITH, B. P. (1990) Diseases of the respiratory system. In Large Animal Internal Medicine. St Louis, Mosby. pp 489-618

\section{Assessment of Pneumocystis species carriage in captive primates}

\section{Demanche, T. Petit, P. Moisson, F. Ollivet, J. Rigoulet, R. Chermette, E, Dei-CAS, A. E. Wakefield, J. Guillot}

Pneumocystis species are recognised as major opportunistic fungal pathogens which cause life-threatening pneumonia in severely ill or malnourished mammals, especially primates. In human beings, Pneumocystis pneumonia remains the most common initial manifestation of acquired immunodeficiency syndrome (AIDS) (Roux and others 1998). Cancer patients and transplant recipients may also be affected. In other primate species, cases of pneumocystosis have regularly been reported in animals with naturally occurring or experimentally induced immunodeficiency syndromes. Most cases have concerned macaque species infected with either simian immuno- deficiency virus (Baskerville and others 1991, Furuta and others 1993, Vogel and others 1993, Yanai and others 1999) or chimaeric simian-human immunodeficiency virus (Shibata and others 1997, Durand-Joly and others 2000). New World primates may also be affected (Long and others 1975, Poelma 1975, Richter and others 1978, Kobayashi and others 1999). In most cases, the presence of Pneumocystis species was detected in lung sections after postmortem examination. To the authors' knowledge, an epidemiological survey concerning the carriage of Pneumocystis species in captive primates has not been attempted. This short communication describes a study to determine the frequency of Pneumocystis species in captive primates in France.

Lung tissue samples from non-human primates were obtained at four French zoological parks (La Palmyre, Mulhouse, Vincennes and Jardin des Plantes de Paris). The lungs were frozen after postmortem examination and stored at $-20^{\circ} \mathrm{C}$ before DNA extraction. For each animal, data, including the animal's specific identification, age, sex, date of death and postmortem examination results, were retrieved from medical records and reported on a standardised form. The number and the age of conspecific primates which had been living with the animal were also recorded.

The lungs were finely minced, homogenised by crushing and subjected to sequential membrane filtration (Ceré and others 1997). The final filtrates were used for direct examination and DNA extraction. Cystic forms of Pneumocystis species were detected in $2.5 \mu \mathrm{l}$ air-dried smears stained with toluidine blue $\mathrm{O}$ (Chalvardjian and Grave 1973). A volume of $100 \mu \mathrm{l}$ from the final filtrates of lung extracts was then frozen at $-20^{\circ} \mathrm{C}$ and digested with proteinase $\mathrm{K}(1 \mathrm{mg} / \mathrm{ml})$. A phenol-chloroform extraction was then performed, with a final precipitation in ethanol. The presence of Pneumocystis DNA in the lung was assessed by nested PCR at the mitochondrial large subunit (mtLSU) ribosomal RNA gene (Wakefield 1996). The primer sets pAZ102-H/pAZ102-E (5'-GATGGGTGTTTCCAAGCCCA3'/5'-GTGTACGTTGCAAAGTACTC-3') and PAZ102-X/R1/pAZ102-Y/R1 (5'-GGGAATTCGTGAAATACAAATCGGACTAGG-3'/5'-GGGAATTCT CACTTAATATTAATTGGGGAGC-3') were used. Primers paZ102-H and pAZ102-E are routinely used for the diagnosis of pneumocystosis in human beings. Primers PAZ102-X/R1 and pAZ102Y/R1 were initially designed for the detection of Pneumocystis species DNA in environmental samples, but they were shown to be appropriate for the detection of Pneumocystis species in lung tissue samples from non-human primates as well (Demanche and others 2001). Negative controls were included in both the DNA extraction and PCR amplification stages to monitor for possible contamination. The PCR products were electrophoresed in 2 per cent agarose gels and visualised by ethidium bromide staining.

Fisher's exact probability tests were carried out using Epi Info 2000 software (version 1.1.2) to compare the prevalences of Pneumocystis species carriage in the simian populations. $\mathrm{P}<0.05$ was considered to be significant.

Lung tissue samples were collected from 83 primates representing 26 different species; 15 New World species (63 animals) and 11 Old World species (20 animals). Forty-one of the primates were female, 34 were male and eight were too young for their sex to be determined. Twenty-five samples were collected from unweaned primates, 12 from subadult animals and 46 from sexually mature adults. Serological analyses proved that none of the Old World primates was infected by an immunosuppressive retrovirus. There was no history of the use of immunosuppressive or cytotoxic medication.

Pneumocystis cysts were observed in lung samples from seven New World primates (one squirrel monkey, two Geoffroy's marmosets, one red-handed tamarin, one Goeldi's monkey and two Weddell's tamarins). However, there was no clinical or pathological evidence of pneumocystosis in these 
animals. Cysts were not found in any of the 20 lung tissue samples from the Old World primates. A positive Pneumocystis mtLSU rRNA gene amplification was obtained with all lung samples in which Pneumocystis cysts were detected. A positive amplification was obtained with 15 other lung samples.

Overall, the prevalence of Pneumocystis species carriage was 26.5 per cent. The prevalence of carriage was similar in New World ( 28.6 per cent) and Old World ( 20.0 per cent) primates. As shown in Table 1, the age, sex, date of death and the size of the group of origin did not influence the frequency of Pneumocystis DNA detection.

The various causes of death of the 83 primates included in the study are listed in Table 2. The frequency of Pneumocystis species DNA detection was significantly higher in primates with an underlying illness ( 33.9 per cent) than in animals that had died from trauma or been euthanased because of aggressive behaviour $(4.8$ per cent $)(\mathrm{P}<0 \cdot 01)$. Pulmonary diseases and anaemia were the most frequent underlying diseases in primates for which a positive PCR amplification was obtained (Table 2).

Although Pneumocystis pneumonia continues to be a common AIDS-defining illness associated with significant mortality in human beings, many questions about the epidemiology of the infection and the transmission of Pneumocystis species remain unanswered. In the absence of standardised methods of in vitro cultivation of Pneumocystis organisms, the use of an animal model is still required. Because Pneumocystis organisms derived from different mammalian hosts exhibit striking molecular and antigenic variation at a number of genetic loci, it has become clear that the genus contains a large number of distinct species (Stringer and others 2001). These Pneumocystis species have undergone a prolonged process of genetic and functional adaptation to each mammalian host species (Guillot and others 2001). A recent study demonstrated that specific mitochondrial and genomic DNA sequences of Pneumocystis species could be attributed to each primate species (Demanche and others 2001). The genetic divergence among primate-derived Pneumocystis biotypes varied in proportion to the degree of the phylogenetic divergence among the corresponding host species, suggesting a process of co-evolution. Non-human primates may thus constitute a valuable population for the analysis of Pneumocystis species biology and the epidemiology of corresponding infections.

In the present study, no pneumocystosis was diagnosed, but the presence of Pneumocystis DNA was demonstrated in 22 of the 83 primates studied. However, the positivity of nested PCR only, with negative microscopical examination in 15 of the 22 lung samples, suggests a low burden of Pneumocystis organisms in the lungs of the primates. These results are in accordance with previous studies concerning HIV-negative human beings with no apparent pneumocystosis. Probst and others (2000) obtained positive nested PCRs in 36 of 163 respiratory samples $(22 \cdot 1$ per cent) from patients with chronic pulmonary diseases. Patients with chronic obstructive pulmonary disease or lung cancer had the highest prevalence of Pneumocystis species carriage ( 40.5 per cent and 35.0 per cent, respectively). When postmortem lung tissue samples from individuals without predisposing diseases were investigated, no evidence, or only a very low rate of prevalence, of Pneumocystis carriage was detected (Peters and others 1992).

Recent studies have demonstrated that Pneumocystis DNA can frequently be detected in nasopharyngeal aspirates from healthy infants (Nevez and others 2001, Vargas and others 2001). These studies raised the hypothesis that they may be an infectious reservoir of Pneumocystis species in the human community. Similar observations have been made in some other mammalian species. In wild rabbits, a positive amplification was systematically obtained from samples collected

\begin{tabular}{|c|c|c|}
\hline Characteristics of animals & Number of animals & $\begin{array}{l}\text { Number }(\%) \text { of positive } \\
\text { results in nested PCR }\end{array}$ \\
\hline \multicolumn{3}{|l|}{ Sex } \\
\hline Male & 34 & $11(32.4)$ \\
\hline Female & 41 & $10(24.4)$ \\
\hline Not determined & 8 & $1(12.5)$ \\
\hline \multicolumn{3}{|l|}{ Age } \\
\hline Unweaned & 25 & $6(24 \cdot 0)$ \\
\hline Subadult & 12 & $3(25.0)$ \\
\hline Adult & 46 & $13(28 \cdot 3)$ \\
\hline \multicolumn{3}{|c|}{ Size of the social group of origin } \\
\hline Five animals or fewer & 50 & $13(26-0)$ \\
\hline More than five animals & 33 & $9(27 \cdot 3)$ \\
\hline \multicolumn{3}{|c|}{$\begin{array}{l}\text { Presence of unweaned primates in } \\
\text { the social group of origin }\end{array}$} \\
\hline Yes & 38 & $8(21 \cdot 1)$ \\
\hline No & 45 & $14(31 \cdot 1)$ \\
\hline \multicolumn{3}{|l|}{ Season of death } \\
\hline Spring & 13 & $4(30 \cdot 8)$ \\
\hline Summer & 29 & $10(34.5)$ \\
\hline Autumn & 16 & $4(25-0)$ \\
\hline Winter & 25 & $4(16.0)$ \\
\hline
\end{tabular}

from animals less than one month old (Guillot and others 1999). A large retrospective study concerning Pneumocystis infection in pigs indicated that animals from herds in which adult and young pigs shared the same airspace were more heavily infected than those from herds in which adults and weaners were reared separately (Kondo and others 2000). The results obtained in the present study did not confirm the possible role of young animals as reservoirs of Pneumocystis species, because the sizes of the groups of origin and the presence of unweaned animals did not influence the prevalence of Pneumocystis carriage in lung tissue samples (Table 1). However, the presence of Pneumocystis species DNA in twin stillborn marmosets (Callithrix jacchus) suggested that vertical transmission of Pneumocystis species may occur in nonhuman primates. This mode of transmission was ruled out in mice (Ito and others 1991) but is suspected in human beings (Mortier and others 1995) and has been proved in rabbits (Ceré and others 1997).

Another reservoir of Pneumocystis species could be the environment. This possibility would account for the seasonal variations in Pneumocystis carriage observed in wild rodents and insectivores in Finland (Laakkonen and others 1999). As shown in Table 1, the prevalence of Pneumocystis species was higher in primates which had died in the spring or summer (33.3 per cent) than in the colder seasons (19.5 per cent). However, these differences were not significant. Only a few studies have indicated seasonal variations in the occurrence of human cases of pneumocystosis (Miller and others 1992, Vanhems and others 1992).

The presence of an underlying disease seemed to be the only factor that influenced the prevalence of Pneumocystis

TABLE 2: Correlation of Pneumocystis species mtLSU rRNA gene amplification with underlying diseases

\begin{tabular}{lcc}
$\begin{array}{l}\text { Cause } \\
\text { of death }\end{array}$ & $\begin{array}{c}\text { Number } \\
\text { of animals }\end{array}$ & $\begin{array}{c}\text { Number (\%) of positive } \\
\text { results in nested PCR }\end{array}$ \\
\hline $\begin{array}{l}\text { Trauma or euthanasia } \\
\begin{array}{l}\text { Neonatal pathology } \\
\text { Anaemia (infectious } \\
\text { or autoimmune) }\end{array}\end{array}$ & 21 & $1(4 \cdot 8)$ \\
$\begin{array}{l}\text { Respiratory infectious } \\
\text { diseases }\end{array}$ & 8 & $2(25.0)$ \\
$\begin{array}{l}\text { Digestive infectious } \\
\text { diseases }\end{array}$ & 6 & $4(50.0)$ \\
\begin{tabular}{l} 
Other diseases \\
\hline
\end{tabular} & 21 & $4(66.7)$ \\
\hline
\end{tabular}


species in lung tissue samples from captive primates. Onethird of the study group, which was composed of sick nonhuman primates, had detectable amounts of Pneumocystis DNA in their lungs. However, it is not known whether these animals were only transient carriers or truly colonised animals and reservoirs of the infection.

\section{References}

BASKERVILLE, A., DOWSETT, A. B., COOK, R. W., DENNIS, M. J., CRANAGE, M. P. \& GREENAWAY, P. (1991) Pneumocystis carinii pneumonia in simian immunodeficiency virus infection: immuno-histological and scanning and transmission electron microscopical studies. Journal of Pathology 164, 175-185

CERÉ, N., POLACK, B., CHANTELOUP, N. K. \& COUDERT, P. (1997) Natural transmission of Pneumocystis carinii in nonimmunosuppressed animals early contagiousness of experimentally infected rabbits. Journal of Clinical Microbiology 35, 2670-2672

CHALVARDIIAN, A. M. \& GRAVE, L. A. (1973) A new procedure for the identification of Pneumocystis carinii cysts in tissue sections and smears. Journal of Clinical Pathology 16, 383-384

DEMANCHE, C., BERTHELEMY, M., PETIT, T., POLACK, B., WAKEFIELD, A. E., DEI-CAS, E. \& GUILLOT, J. (2001) Phylogeny of Pneumocystis carinii from 18 primate species confirms host specificity and suggests coevolution with hosts. Journal of Clinical Microbiology 39, 2126-2133

DURAND-JOLY, I., WAKEFIELD, A. E., PALMER, R. J., DENIS, C. M., CREUSY, C., FLEURISSE, L., RICARD, I., GUT, J. P. \& DEI-CAS, E. (2000) Ultrastructural and molecular characterisation of Pneumocystis carinii isolated from a rhesus monkey (Macaca mulatta). Medical Mycology 38, 61-72 FURUTA, T., FUJITA, M., MUKAI, R., SAKAKIBARA, I., SATA, T., MIKI, K., HAYAMI, M., KOJIMA, S. \& YOSHIKAWA, Y. (1993) Severe pulmonary pneumocystosis in simian acquired immunodeficiency syndrome induced by simian immunodeficiency virus: its characterisation by the polymerasechain-reaction method and failure of experimental transmission to immunodeficient animals. Parasitology Research 79, 624-628

GUILLOT, J., CHEVALIER, V., QUENEY, G., BERTHELEMY, M., POLACK, B., LACUBE, P., ROUX, P. \& CHERMETTE, R. (1999) Acquisition and biodiversity of Pneumocystis carinii in a colony of wild rabbits (Oryctolagus cuniculus). Journal of Eukaryotic Microbiology 46, S94

GUILLOT, J., DEMANCHE, C., HUGOT, J. P., BERTHELEMY, M., WAKEFIELD, A., DEI-CAS, E. \& CHERMETTE, R. (2001) Parallel phylogenies of Pneumocystis species and their mammalian hosts. Journal of Eukaryotic Microbiology 48 (Suppl), 113S-115S

ITO, M., TSUGANE, T., KOBAYASHI, K., KURAMOCHI, T., HIOKI, K. FURUTA, T. \& NOMURA, T. (1991) Study on placental transmission of Pneumocystis carinii in mice using immunodeficient S(II) mice as a new animal model. Journal of Protozoology 38, S218-S219

KOBAYASHI, R., SAKAKIBARA, I., FURUTA, T., KIKUCHI, T. \& YOSHIKAWA, Y. (1999) Opportunistic Pneumocystis carinii infection in redbellied tamarins (Saguinus labiatus). Experimental Animals 48, 55-57

KONDO, H., HIKITA, M., ITO, M. \& KADOTA, K. $(2000)$ Immunohistochemical study of Pneumocystis carinii infection in pigs: evaluation of Pneumocystis pneumonia and a retrospective investigation. Veterinary Record 147, 544-549

LAAKKONEN, J., HENTTONEN, H., NIEMIMAA, J. \& SOVERI, T. (1999) Seasonal dynamics of Pneumocystis carinii in the field vole, Microtus agrestis, and in the common shrew, Sorex araneus, in Finland. Parasitology 118, 1-5

LONG, G. G., WHITE, J. D. \& STOOKEY, J. L. (1975) Pneumocystis carinii infection in splenectomised owl monkeys. Journal of the American Veterinary Medical Association 165, 651-654

MILLER, R. F., GRANT, A. D. \& FOLEY, N. M. (1992) Seasonal variation in presentation of Pneumocystis carinii pneumonia. Lancet 339, 747-748

MORTIER, E., POUCHOT, J., BOSSI, P. \& MOLINIE, V. (1995) Maternal-fetal transmission of Pneumocystis carinii in human immunodeficiency virus infection. New England Journal of Medicine 332, 825

NEVEZ, G., TOTET, A., PAUTARD, J. C. \& RACCURT, C. (2001) Pneumocystis carinii detection using nested-PCR in nasopharyngeal aspirates of immunocompetent infants with bronchiolotis. Journal of Eukaryotic Microbiology $\mathbf{4 8}$, S122-S123

PETERS, S. E., WAKEFIELD, A. E., SINCLAIR, K., MILLARD, P. R. \& HOPKIN J. M. (1992) A search for Pneumocystis carinii in postmortem lungs by DNA amplification. Journal of Pathology 166, 195-198

POELMA, F. G. (1975) Pneumocystis carinii in zoo animals. Zeitschrift für Parasitenkund 46, 61-68

PROBST, M., RIES, H., SCHMIDT-WIELAND, T. \& SERR, A. (2000) Detection of Pneumocystis carinii DNA in patients with chronic lung diseases. European Journal of Clinical Microbiology and Infectious Diseases 19, 644-645
RICHTER, C. B., HUMASON, G. L. \& GOLDBOLD, J. H. Jr. (1978) Endemic Pneumocystis carinii in a marmoset colony. Journal of Comparative Pathology 88, $171-180$

ROUX, P., HA, M. C., BRUCKer, G. \& COSTAGLiOlA, D. (1998) Pneumocystis and pneumocystosis in Europe at the end of the 20th century. FEMS Immunology and Medical Microbiology 22, 87-91

SHIBATA, R., MALDARElli, F., SIEMON, C., MATANO, T., PARTA, M., MILLER, G., FREDRICKSON, T. \& MARTIN, M. A. (1997) Infection and pathogenicity of chimeric simian-human immunodeficiency virus in macaques: determinants of high virus loads and CD4 cell killing. Journal of Infectious Diseases 176, 362-373

STRINGER, J. R., CUSHION, M. T. \& WAKEFIELD, A. E. (2001) New nomenclature for the genus Pneumocystis. Journal of Eukaryotic Microbiology 48 (Suppl), 184S-189S

VANHEMS, P., HIRSCHEL, B. \& MORABIA, A. (1992) Seasonal incidence of Pneumocystis carinii pneumonia. Lancet 339, 1182

VARGAS, S., HUGHES, W. T., SANTOLAYA, M. E., ULLOA, A. V., PONCE C. A., CABRERA, C. E., CUMSILLE, F. \& GIGLIOTTI, F. (2001) Search for primary infection by Pneumocystis carinii in a cohort of normal, healthy infants. Clinical Infectious Diseases 32, 855-861

VOGEL, P., MILLER, C. J., LOWENSTINE, L. L. \& LACKNER, A. A. (1993) Evidence of horizontal transmission of Pneumocystis carinii pneumonia in simian immunodeficiency virus-infected rhesus macaques. Journal of Infectious Diseases 168, 836-843

WAKEFIELD, A. E. (1996) DNA sequences identical to Pneumocystis carinii f sp carinii and Pneumocystis carinii $\mathrm{f}$ sp hominis in samples of air spora. Journal of Clinical Microbiology 34, 1754-1759

YANAI, T., SIMON, M. A., DODDY, F. D., MANSFIELD, K. G., PAULEY, D. \& LACKNER, A. A. (1999) Nodular Pneumocystis carinii pneumonia in SIVinfected macaques. Veterinary Pathology 36, 471-474

\section{ABStRACT}

\section{Morphological changes induced by oxfendazole in early stage Taenia solium cysticerci}

PIGS infected with early stage Taenia solium cysticerci were treated with a single dose of $30 \mathrm{mg} / \mathrm{kg}$ oxfendazole. One day later there were no obvious changes in the general appearance of the larvae, but under the electron microscope there was an apparent reduction in the number of microtriches and the tegument had been completely disrupted and its cells had accumulated many granules, some of which were electronlucent and others had an electron-dense core. By the second day only the fibrous skeleton and muscle cells were preserved, and by the fifth day the cysticerci were all in an advanced stage of degeneration. By 45 days all the cysts were calcified.

YONG-JIE, L., QING-ZHANG, L. \& YAN-HONG, H. (2003) Morphological changes to early stage Taenia solium cysticerci following oxfendazole treatment. Veterinary Journal 165, 73-77

\section{Correction}

Abstract (VR, May 31, p 692). Efficacy of magnets for the treatment of traumatic reticuloperitonitis in cows. The reference details given for this abstract were incorrect. The correct reference should have been as follows: Braun, U., Gansohr, B. \& Fluckiger, M. (2003) Radiographic findings before and after oral administration of a magnet in cows with traumatic reticuloperitonitis. American Journal of Veterinary Research 64, 115-120. The error is regretted. 


\section{veterinary Assessment of Pneumocystis species carriage in captive primates}

C. Demanche, T. Petit, P. Moisson, et al.

Veterinary Record 2003 152: 811-813

doi: 10.1136/vr.152.26.811

Updated information and services can be found at:

http://veterinaryrecord.bmj.com/content/152/26/811.citation

These include:
Email alerting Receive free email alerts when new articles cite this article. Sign up in service the box at the top right corner of the online article.

Notes

To request permissions go to:

http://group.bmj.com/group/rights-licensing/permissions

To order reprints go to:

http://journals.bmj.com/cgi/reprintform

To subscribe to BMJ go to:

http://group.bmj.com/subscribe/ 